\title{
Development of Bean Plants in Soil Contaminated With TRIFLOXYSULFURON-SODIUM AFTER Stizolobium aterrimum AND Canavalia ensiformis Cultivation ${ }^{1}$
}

\author{
Desenvolvimento de Plantas de Feijão em Solo Contaminado com Trifloxysulfuron-Sodium, \\ Após o Cultivo de Stizolobium aterrimum e Canavalia ensiformis
}

\author{
PROCÓPIO, S.O. ${ }^{2}$, SANTOS, J.B. ${ }^{3}$, PIRES, F.R. ${ }^{4}$, SILVA, A.A. ${ }^{5}$, SANTOS, E.A. ${ }^{6}$ and \\ CARGNELUTTI FILHO, A. ${ }^{7}$
}

\begin{abstract}
Phytoremediation, the use of plants to decontaminate soils and water resources from organic pollutants such as herbicides, is economically and environmentally a promising technique applied in many areas, including agriculture. The objective of this work was to evaluate the development of bean plants cultivated in the field, in soil with different levels of trifloxysulfuron-sodium contamination, following cultivation of two green manure species, as well as to evaluate the possibility of recontamination of the area by such herbicide with the straw permanence on the soil. The experiment was carried out in Coimbra, MG, Brazil, on a sandy clayey Red - Yellow Argisol from March to November 2003. Four levels of soil contamination with trifloxysulfuron-sodium $\left(0.00 ; 3.75 ; 7.50\right.$; and $\left.15.00 \mathrm{~g} \mathrm{ha}^{-1}\right)$ were used as well as the following five types of cultivation prior to bean sowing in the area after herbicide application: black velvet beans (Stizolobium aterrimum) followed by removal of straw; $S$. aterrimum, followed by permanence of straw; jack bean (Canavalia ensiformis), followed by removal of straw; $C$. ensiformis followed by permanence of straw; and without prior cultivation, weed-free (weeded control). The leguminous plants were kept in the area for 65 days, cut close to the soil, and with its aerial part left or not on the surface of the experimental plot, depending on the treatment. Fifteen days after the species were cut, bean was sown in the area. At 45 days after emergence (DAE) of the bean plants, plant height and dry mass of the aerial part were evaluated. Grain productivity was determined during harvest. Height, dry matter of the aerial part and grain productivity of the bean plants, cultivated in an area previously contaminated with trifloxysulfuron-sodium at any of the levels tested, were higher with prior cultivation of $S$. aterrimum or $C$. ensiformis. At the lowest level of herbicide contamination, prior cultivation of $C$. ensiformis was found to be more efficient than that of $S$. aterrimum in mitigating the harmful effects of trifloxysulfuron-sodium on bean grain production. The permanence of the straw of the green manure species during the bean cycle did not harm the development of the plants or caused culture productivity losses, indicating that straw permanence in the area does not promote recontamination of the area.
\end{abstract}

Keywords: Phaseolus vulgaris, phytoremediation, carryover, green manures.

RESUMO - A utilização de plantas para descontaminar solos e recursos hidricos de poluentes orgânicos, como os herbicidas, denominada fitorremediação, desponta como técnica promissora tanto econômica como ambientalmente, sendo direcionada inclusive para a agricultura. O objetivo deste trabalho foi avaliar o desenvolvimento de plantas de feijão cultivadas em campo, em solo com diferentes niveis de contaminação do herbicida trifloxysulfuron-sodium, após o cultivo prévio

Recebido para publicação em 4.5.2006 e na forma revisada em 27.2.2007.

Faculdade de Agronomia da Universidade de Rio Verde - FESURV, 75901-970 Rio Verde-GO, <soprocopio@yahoo.com.br>. ${ }^{3}$ Doutor em Produção Vegetal, Prof. de Agronomia da Faculdade de Ciências Agrárias, Universidade Vale do Rio Doce - FAAG/ UNIVALE, Rua Israel Pinheiro, 2000, Bairro Universitário, 35020-220 Governador Valadares-MG, <jbarbosa@ univale.br>. ${ }^{4}$ Dep. de Ciências da Saúde, Biológicas e Agrárias do Centro Universitário Norte do ES/UFES, 29933-480 São Mateus-ES, <fabiopires@ ceunes.ufes.br>, ${ }^{5}$ Prof. Associado, Dep. de Fitotecnia, Universidade Federal de Viçosa - DFT/UFV, 36570-000 Viçosa-MG; ${ }^{6}$ Bolsista de Iniciação Científica - CNPq/UFV. ${ }^{7}$ Prof. do Instituto de Matemática da Universidade Federal do Rio Grande do Sul - UFRGS, 90040-060 Porto Alegre-RS. 


\begin{abstract}
de duas espécies de adubos verdes, bem como a possibilidade de recontaminação da área pelo herbicida com a permanência da palhada sobre o solo. O experimento foi conduzido em campo em Coimbra, MG, em um Argissolo Vermelho-Amarelo de textura argilo-arenosa. Avaliaram-se quatro niveis de contaminação do solo com trifloxysulfuron-sodium $\left(0,00 ; 3,75 ; 7,50 ;\right.$ e 15,00 $\left.\mathrm{g} \mathrm{ha}^{-1}\right) \mathrm{e}$ cinco tipos de cultivo prévio à semeadura do feijão na área após aplicação do herbicida: cultivo de mucuna-preta (Stizolobium aterrimum) com posterior retirada da sua palhada; cultivo de mucuna-preta seguido da permanência da palhada; cultivo de feijão-de-porco (Canavalia ensiformis) com retirada da palhada em seguida; cultivo de feijão-de-porco com posterior permanência da palhada; e sem cultivo prévio, com a área mantida no limpo (testemunha capinada). As plantas das leguminosas de cobertura foram mantidas na área por 65 dias, quando foram cortadas rente ao solo, sendo sua parte aérea deixada ou não sobre a superfície da parcela experimental, dependendo do tratamento. Quinze dias após o corte das espécies, foi semeada na área a cultura do feijão. Aos 45 dias após a emergência (DAE) das plantas de feijão, avaliaram-se a altura de plantas e a massa seca da parte aérea. A produtividade de grãos foi determinada por ocasião da colheita. A altura de plantas, a massa seca da parte aérea e a produtividade de grãos de feijão, cultivado em área com contaminação prévia do trifloxysulfuron-sodium em qualquer dos niveis testados, foram superiores quando se realizou o cultivo prévio na área com mucunapreta ou feijão-de-porco. No menor nivel de contaminação do herbicida, o cultivo prévio de feijãode-porco se mostrou mais eficiente, em relação ao da mucuna-preta, em mitigar os efeitos deletérios do trifloxysulfuron-sodium à produção de grãos de feijão. A manutenção da palhada das espécies de adubos verdes durante o ciclo do feijão não prejudicou o desenvolvimento das plantas e não provocou perdas na produtividade da cultura, indicando que a permanência da palhada na superficie do solo não promove a recontaminação da área.
\end{abstract}

Palavras-chave: Phaseolus vulgaris, fitorremediação, carryover, adubos verdes.

\section{INTRODUCTION}

Phytoremediation is the use of plants and their associated microbiota in the decontamination of soil and water, exploiting the ability some plant species have of removing/ extracting and/or mineralizing xenobiotics, as well as tolerance of such plants to contaminants (Wilson et al., 2000). This technique is an agronomic alternative for crop systems that need to remove herbicides of high persistence in the soil, such as trifloxysulfuronsodium, which requires a waiting period of 8 months following its application for the sowing of susceptible species. Some leguminous plants have also been tested for phytoremediation of non-herbicide organic compounds, such as leucene (Leucene leucocephala var. K636), which has proved efficient in absorbing and metabolizing trichloethylene (TCE) (Doty et al., 2003).

The role played by plants in remediation of organic contaminants, especially herbicides, seems to be the result of rhizodegradation and/ or phytodegradation. The first involves the release of exudates and enzymes through the root of the plants enhancing the biochemical changes and/or pollutant mineralization, by stimulating the microbial activity in the rhizosphere and through the association with micorrhyzal fungi, also known as phyto stimulation. (Cunninghan et al., 1996; Wilson, et al., 2000). Rhizodegradation has been the mechanism attributed to the phytoremediating action of the species Kochia scoparia on the herbicides atrazine and metolachlor (Anderson et al., 1994; Anderson \& Coats, 1995; Perkovich et al., 1996).

Nevertheless, phytodegradation, which means contaminant uptake and metabolism in the plant tissues (Ferro et al., 1994), is also one of the major mechanisms of action in herbicide remediation. Such mechanism is associated with the tolerance some plants have to certain herbicides (Holt et al., 1995).

According with Mannervik and Danielson (1988), some enzymes can metabolize several xenobiotics, such as herbicides, thereby allowing plants to detoxify. Evidences for such affirmation were obtained by Catâneo et al. (2003), in the degradation of the herbicide glyphosate in maize seedlings by the enzyme glutathione S-transferase. 
Phytodegradation of the herbicide atrazine was also evident in the tree species Populus sp., which promoted its uptake and transformation in to ameline, a metabolite completely hydroxylated and dealkalined, with out mineralization of the herbicide into $\mathrm{CO}_{2}$ being confirmed, however (Burken \& Schnoor, 1997). These authors determined that a fraction (around 15\%) of the labile ring of atrazine was incorporated into the mass as a linked residue. Studies conducted by. Burken \& Schnoor (1996) indicated that the species Populus deltoides nigra DN34 could absorb the most part of the atrazine applied, without any adverse effects on the tree species tested.

Rice et al. (1997) found answers supporting the hypothesis that the presence of herbicidetolerant aquatic vegetation may accelerate the removal and biotransformation of metolachlor and atrazine in waters contaminated with these herbicides. Following 16 days of incubation, only $1.44,4.6$ and $22.7 \%$ of the ${ }^{14} \mathrm{C}$-metolachlor applied remained on the water surface of the system containing Ceratophyllum demersum, Elodea canadensis and Lemna minor, while $61 \%$ of the ${ }^{14} \mathrm{C}$-metolachlor applied persisted on the water surface of the systems without plants. For ${ }^{14} \mathrm{C}$-atrazine, 41.3 and $63.2 \%$ of the amount applied remained in the plant systems containing $C$. demersum and E. canadensis, respectively, and $85 \%$ of ${ }^{14} \mathrm{C}$-atrazine was detected in the water containing $L$. minor.

The most desirable trait the phytoremediating species should have to act on phytodegradation or phytotransformation, excluding tolerance, which they obviously must exhibit to the contaminant, seems to be their capacity to uptake and metabolize (Schnoor, 1997; Kvesitadze et al., 2001). The efficiency of the remediation process is ensured by promoting uptake, i.e., removal of amounts resulting in acceptable levels in the soil or water, followed by phytotransformation leading to mineralization, which generally occurs in a small percentage (Newman et al., 1997), or in the formation of non-toxic metabolites or less toxic than the original molecule. This becomes even more important when phytoremediation is used in agricultural systems involving crop succession/rotation.

The use of phytoremediation has been commonly studied in sites where contamination was the result of product spill or in specific ones such as industrial areas, over a long period of time (Macek et al., 2000). Little is known about the applicability of phytoremediation in farming systems and the time necessary for complete or minimum decontamination to allow the succession cultivation of sensitive species and return of the residues of the remediating plant into the soil by using it as a source of straw under the no-till system, for instance. In this case, in order to maintain the straw on the soil, the herbicide must be mineralized or, at least, transformed into a non-toxic or less toxic metabolite, with undesirable situations occurring when only the accumulation of the compound into organelles, such as the vacuole, takes place, or the herbicide may be transformed into even more toxic metabolites (Burken \& Schnoor, 1997; Fernandes et al., 1999). In such situations, the aerial part of the remediating plants must be removed from the area.

The objective of this work was to evaluate the development of bean plants cultivated in the field, in soil under different levels of contamination of the herbicide trifloxysulfuronsodium, following cultivation of two species used as green manure, as well as to verify whether maintaining the straw of these leguminous plants in the area would promote recontamination of the herbicide.

\section{MATERIAL AND METHODS}

An experiment was carried out in a field located at the Experimental Station of Coimbra, MG, Brazil of the Universidade Federal de Viçosa. The soil of the experimental area was classified as Red-Yellow Argisol, of sandyclayey texture, with its physical-chemical characterization being shown in Table 1 . The experiment period was from March to November 2003.

The experiment design was randomized blocks in a $4 \times 5$ factorial scheme, with four repetitions. The treatments were constituted by the combination of four contamination levels of the herbicide trifloxysulfuron-sodium (0.00; 3.75; 7.50; and $15.00 \mathrm{~g} \mathrm{ha}^{-1}$ ) and five types of cultivation prior to bean sowing in the area, following soil contamination with the 
herbicide: cultivation of black velvet bean (Stizolobium aterrimum) followed by removal of straw; cultivation of $S$. aterrimum, with permanence of straw; cultivation of jack bean (Canavalia ensiformis) followed by removal of straw; cultivation of C. ensiformis followed by permanence of straw; and without prior cultivation, weed-free (weeded control ).

Conventional soil preparation was performed before sowing, consisting of one plowing and two diskings. After soil preparation, the area was mechanically furrowed, with each experimental unit area being $12 \mathrm{~m}^{2}(4 \mathrm{~m}$ $\mathrm{x} 3 \mathrm{~m})$. The herbicide trifloxysulfuron-sodium was applied in the plots, simulating different levels of contamination, using a back spray pressurized with carbonic gas $\left(\mathrm{CO}_{2}\right)$, with the equivalent of $200 \mathrm{~L} \mathrm{ha}^{-1}$ being applied.

The spacing used for sowing of $S$. aterrimum and C. ensiformis was $0.30 \mathrm{~m}$, this operation being manually performed. Ten and eight seeds of $S$. aterrimum and C. ensiformis were sown per meter, respectively, corresponding to four times the plant density recommended for green manure. The plants of these two species were kept in the area for 65 days and cut close to the soil, with their aerial part being left or not on the surface of the experimental plot, depending on the treatment. Fifteen days after the species were cut, the experimental area was again furrowed and fertilized according to soil analysis and requirements of the bean plant (Phaseolus vulgaris, Vermelho Coimbra cv.), a species cultivated in the area to indicate the presence or absence of the herbicide, at levels likely to cause injuries to or harm the growth of the plants. The spacing between lines used for bean sowing was $0.50 \mathrm{~m}$, with 10 seeds sown per meter. During the culture cycle, the total experimental area was kept weed - free, by means of manual weeding.

At 45 days after emergence (DAE) of the bean plants, plant height was evaluated, with the apical meristem being adopted as a basis for measurement; the dry mass of the aerial part was obtained by weighing the material collected, which was oven-dried in forced air oven $\left(70 \pm 2{ }^{\circ} \mathrm{C}\right)$ for 72 hours. Five plants collected at random per plot were sampled for such evaluations. Also, grain productivity was determined during harvest.
All the variables meeting the hypotheses of variance normality and homogeneity were submitted to analys is of variance, with the effects of the doses of the herbicide trifloxysulfuron-sodium (contamination levels), for each type of cultivation prior to bean sowing being evaluated by regression analysis at $1 \%$ of significance by the $\mathrm{F}$ test; the effects of previous cultivations for each herbicide dose were evaluated by the orthogonal test contrasts at $5 \%$ significance.

\section{RESULTS AND DISCUSSION}

The bean plant height averages, evaluated 45 days after sowing (DAS), are presented in Table 2. In the plots where soil contamination with trifloxysulfuron-sodium was not carried out, no increase or decrease of bean plant height was observed, as a result of previous cultivation of the leguminous species S. aterrimum or C. ensiformis (Table 3 - contrast $\mathrm{X} 1$ ). The previous cultivation of $S$. aterrimum in an area without herbicide resulted in bean plants of the same height, compared to the plants resulting from previous cultivation with C. ensiformis (Table 3 - contrast X2). Also, in the trifloxysulfuron-sodium-free plots, it was verified that the permanence or removal of straw of S. aterrimum or C. ensiformis did not alter the height of the bean plants cultivated under succession (Table 3 - contrasts X3 and $\mathrm{X} 4$ ). These results indicate that the type of previous cultivation, or even absence, did not influence the height of bean plants cultivated in the same area, i.e., without herbicide in the soil. Consequently, no harmful allelopathic effect of the evaluated leguminous plants on the bean cultivated sequentially was observed for this characteristic

When the bean was cultivated in soil contaminated with trifloxysulfuron-sodium applications of 3.75 and $7.50 \mathrm{~g} \mathrm{ha}^{-1}$, it was confirmed that prior cultivation of leguminous plants increased the height of these plants, regardless of whether the species previously cultivated was $S$. aterrimum or $C$. ensiformis and whether the straw of these species was maintained or removed from the area before bean sowing (Table 3 ). The height of the bean plants sown in the plots kept without any type of plant, and that were applied the herbicide 
(3.75 and $7.50 \mathrm{~g} \mathrm{ha}^{-1}$ ) was, on average, twice lower than that of those grown in previously cultivated plots (Table 2). Such facts indicate that prior cultivation of $S$. aterimum and C. ensiformis remediated part of the herbicide present in the soil. It could also be inferred that if herbicide availability was reduced for the bean plants, due to its uptake by the roots of the phytoremediating species, the contaminant may have not been compartmentalized 'intact' in the cellular vacuoles, what could cause a return of these herbicides into the soil, as a result of organic residue decomposition, especially in the case of leguminous plants, which have a relative high tissue decomposition/ mineralization rate. Several studies have shown that, in general, most of the organic compounds undergo a transformation in the plant cells before being isolated in vacuoles or linked to insoluble cellular structures, such as lignin (Salt et al., 1998), and that the contaminant can cause toxicity to the very plant that absorbed it, as the enzymes cannot continue performing its degradation any longer (Dietz \& Schnoor, 2001).

The application of the highest dose of trifloxy sulfuron-s od ium (15.00 $\left.\mathrm{g} \mathrm{ha}^{-1}\right)$, equivalent to double the commercial dose recommended by the manufacturer for use in the bean culture, led to a reduction in the height of the bean plants, when prior cultivation with $S$. aterrimum or $C$. ensiformis was not carried out (Table 3 - contrast X1), such height being, on average, $30.50 \mathrm{~cm}$ (Table 2). This reconfirms the effective participation of these leguminous plants in the remediation of this xenobiotic species. At this level of contamination, the permanence of S. aterimum straw was found to increase the height of the bean plants, a fact not observed for the species C. ensiformis. Such observations reaffirm the idea that prior cultivation of these green manures does not leave toxic allelo-chemicals in the soil nor it is necessary to remove the mass of the aerial part of the remediating plants from the area before bean sowing due to a suspicion of potential risk of herbicide return in to the soil with subsequent culture intoxication. This scenario would make viable the technique of phytoremediation of herbicides in farming areas, since removing the aerial part of the species - besides losses due to the addition of organic matter and nutrients into the soil, such as nitrogen, soil protection against erosion and improvement of the soil structural conditions of the soil - would be unviable in large farming areas.

For trifloxysulfuron-sodium to be phytoremediated, it must be either degraded at rhizospheric level in the soil, or absorbed and metabolized in such amounts so as to reduce its concentration to non-toxic levels in the soil. For the second mechanism to work, the organic contaminant must preferentially have the logarithm of the partition constant octagonal-water $\left(\mathrm{k}_{\mathrm{ow}}\right)$ between 1 and 3.5 , what favors its uptake by the plants (Brigss et al., 1982). Trifloxysulfur on-s odium has a logarithm of $\mathrm{k}_{\mathrm{ow}}$, $=1,4$ at $\mathrm{pH} 5.0$, confirming the information that its uptake in tolerant plants, such as cotton, occurs rapidly. After that, it is metabolized extensively. In studies using radioisotopes, it was verified that the original molecule constituted less than $10 \%$

Table 1 - Physicochemical composition of the arable area $(0-20 \mathrm{~cm})$ of a Red-YellowArgisol, Coimbra, MG

\begin{tabular}{|c|c|c|c|c|c|c|c|c|c|c|}
\hline \multicolumn{11}{|c|}{ Granulometric analysis $\left(\mathrm{dag} \mathrm{kg}^{-1}\right)$} \\
\hline \multicolumn{3}{|c|}{ Clay } & \multicolumn{2}{|l|}{ Silt } & Fine sand & \multicolumn{2}{|c|}{ Coarse sand } & \multicolumn{3}{|c|}{ Texture clas sification } \\
\hline \multicolumn{3}{|c|}{34} & \multicolumn{2}{|l|}{12} & 18 & \multicolumn{2}{|c|}{36} & \multicolumn{3}{|c|}{ Sandy clayey } \\
\hline \multicolumn{11}{|c|}{ Chemical analysis } \\
\hline $\mathrm{pH}$ & $\mathrm{P}$ & $\mathrm{K}^{+}$ & $\mathrm{H}+\mathrm{Al}$ & $\mathrm{Al}^{3+}$ & $\mathrm{Ca}^{2+}$ & $\mathrm{Mg}^{2+}$ & $\mathrm{CTC}_{\text {total }}$ & $\mathrm{V}$ & $\mathrm{m}$ & $\mathrm{MO}$ \\
\hline$\left(\mathrm{H}_{2} \mathrm{O}\right)$ & \multicolumn{2}{|c|}{$\left(\mathrm{mg} \mathrm{dm}^{-3}\right)$} & \multicolumn{5}{|c|}{$\left(\mathrm{cmol}_{\mathrm{c}} \mathrm{dm}^{-3}\right)$} & \multicolumn{2}{|c|}{$(\%)$} & $\left.(\text { dag kg })^{-1}\right)$ \\
\hline 5.5 & 7.4 & 76 & 2.7 & 0 & 2.8 & 0.8 & 3.61 & 56 & 0 & 3.68 \\
\hline
\end{tabular}

* Analyses conducted at the Laboratory of Soil Physicochemical Analysis of the Department of Soils of the UFV, according to methodology described by Embrapa (1997). 
Table 2 - Height and dry mass of the aerial part (DMAP) of bean plants (Phaseolus vulgaris Vermelho Coimbra cv.) 45 days after sowing (DAS) and grain productivity in area contaminated with different levels of the herbicide trifloxysulfuronsodium $\left(0.00 ; 3.75 ; 7.0\right.$; and $\left.15.00 \mathrm{~g} \mathrm{ha}^{-1}\right)$, with or without prior cultivation of two green manure species. Coimbra, MG

\begin{tabular}{|c|c|c|c|}
\hline Types of cultivation before bean sowing & Plant height $(\mathrm{cm})$ & DMAP (g per plant) & $\begin{array}{c}\text { Productivity } \\
\left(\mathrm{kg} \mathrm{ha}^{-1}\right)\end{array}$ \\
\hline & \multicolumn{3}{|c|}{ Without herbicide } \\
\hline S. aterrimum with straw kept in the area & 62.48 & 10.19 & 2141 \\
\hline S. aterrimum without straw kept in the area & 70.50 & 12.30 & 2086 \\
\hline C. ensiformis with straw kept in the area & 72.78 & 14.48 & 2249 \\
\hline C. ensiformis without straw kept in the area & 70.68 & 11.30 & 1943 \\
\hline \multirow[t]{2}{*}{ Without prior cultivation with weeded area } & 61.91 & 11.88 & 2311 \\
\hline & \multicolumn{3}{|c|}{ With herbicide $\left(3.75 \mathrm{~g} \mathrm{ha}^{-1}\right)$} \\
\hline S. aterrimum with straw kept in the area & 61.65 & 12.43 & 1923 \\
\hline S. aterrimum without straw kept in the area & 56.10 & 10.23 & 1853 \\
\hline C. ensiformis with straw kept in the area & 67.60 & 12.50 & 2388 \\
\hline C. ensiformis without straw kept in the area & 64.53 & 11.18 & 1898 \\
\hline \multirow[t]{2}{*}{ Withour prior cultivation with weeded area } & 32.28 & 7.15 & 1761 \\
\hline & \multicolumn{3}{|c|}{ With herbicide $\left(7.50 \mathrm{~g} \mathrm{ha}^{-1}\right)$} \\
\hline S. aterrimum with straw kept in the area & 68.65 & 13.53 & 1994 \\
\hline S. aterrimum without straw kept in the area & 62.68 & 9.43 & 1823 \\
\hline C. ensiformis with straw kept in the area & 60.05 & 11.93 & 2212 \\
\hline C. ensiformis without straw kept in the area & 68.90 & 10.40 & 1924 \\
\hline \multirow[t]{2}{*}{ Without prior cultivation with weeded area } & 31.35 & 6.15 & 1687 \\
\hline & \multicolumn{3}{|c|}{ With herbicide $\left(15,0 \mathrm{~g} \mathrm{ha}^{-1}\right)$} \\
\hline S. aterrimum with straw kept in the area & 71.03 & 11.40 & 2057 \\
\hline S. aterrimum without straw kept in the area & 50.50 & 9.68 & 1821 \\
\hline C. ensiformis with straw kept in the area & 58.75 & 11.43 & 1974 \\
\hline C. ensiformis without straw kept in the area & 52.18 & 10.73 & 1800 \\
\hline Without prior cultivation with weeded area & 30.50 & 5.78 & 1630 \\
\hline Mean & 58.75 & 10.70 & 1974 \\
\hline $\mathrm{CV}(\%)$ & 17.10 & 16.47 & 11.53 \\
\hline
\end{tabular}

of the total residue (National..., 2002). Such information indicates that phytodegradation or phytotransformation may be the main factor responsible for decontamination of trifloxysulfuron-sodium in soils following cultivation of $C$. ensiformis and S. aterrimum.

Increased doses of trifloxysulfuron-sodium markedly decreased the height of bean plants cultivated in area previously maintained free from any plant species, only up to $3.75 \mathrm{~g} \mathrm{ha}^{-1}$ (Figure 1a and Table 4). These results make carryover of this herbicide on the bean culture even riskier, since this dose is equivalent to half the commercial dose recommended by the manufacturer, i.e., a level of contamination possibly common after herbicide application in cotton growing areas. In all the treatments involving prior cultivation, no reduction in the height of the bean plants was observed, with the overall averages being described in Table 4.

The bean plants grown in soil without residual activity of trifloxysulfuron-sodium, and not preceded by the cultivation of cover leguminous plants, accumulated dry mass of the aerial part similar to that of those sown after S. aterrimum or C. ensiformis (Table 3, contrast X1), with averages shown in Table 2. 
This led to confirm that, under this situation (absence of herbicides), prior cultivation of leguminous plants neither benefit nor harm mass accumulation by the bean plants, confirming the plant height evaluation results. In the treatments where the green manure species were sown before the bean plants, no differences were detected between the species $S$. aterrimum and C. ensiformis in relation to evaluation of the dry mass of the aerial part (Table 3 - contrast X2). However, when C. ensiformis straw was kept during the bean cycle, production of the aerial part of this culture was found to be higher than that of the treatment with the removal of straw. This behavior was not observed in the $S$. aterrimum plots (Table 3 - contrasts X3 and X4).

Phytoremediation by the leguminous plants S. aterrimum and C. ensiformis was confirmed in the three increasing levels of soil contamination with trifloxysulfuron-sodium (3.75; 7.50 and $15.00 \mathrm{~g} \mathrm{ha}^{-1}$ ), having as indicator the dry mass of the aerial part of the bean plants (Table 3 - contrast X1). The dry mass of the aerial part of the bean plants, cultivated in soil previously applied the herbicide at doses $3.75,7.50$ and $15.00 \mathrm{~g} \mathrm{ha}^{1}$ was $7.15,6.15$ and $5.78 \mathrm{~g}$ per plant, respectively; however, when the leguminous plants S. aterrimum and C. ensiformis were previously cultivated, the mean mass was not lower than 9.43 and $10.40 \mathrm{~g}$ per plant, respectively (Table 2 ). It was also verified that the dry masses of the aerial part of the bean plants cultivated in area where $S$. aterrimum or C. ensiformis had been previously sown did not differ. (Table 3 - contrast X2). Except for the treatments with prior C. ensiformis cultivation in soil applied $7.50 \mathrm{~g} \mathrm{ha}^{-1}$, no alterations were observed in the dry mass of the aerial part of the bean plant evaluated with or without the straw of the leguminous plants tested (Table 3 - contrasts X3 and X4). Both the green manures studied are also considered to be promising species in the phytoremediation of the herbicide tebuthiuron (Pires et al., 2003a, b).

Table 3 - Estimate of the orthogonal contrasts in relation to the variables plant height, dry mass of the aerial part and bean grain productivity in an area contaminated with different levels of the herbicide trifloxysulfuron-sodium, with and without prior cultivation of two species of green manures. Coimbra, MG - Brazil

\begin{tabular}{|c|c|c|c|c|}
\hline \multirow{3}{*}{ Contrast (Xi) } & \multicolumn{4}{|c|}{ Contrast Estimate } \\
\hline & 0.00 & 3.75 & 7.50 & 15.00 \\
\hline & \multicolumn{4}{|c|}{$\left(\mathrm{g} \mathrm{ha}^{-1}\right)$} \\
\hline & \multicolumn{4}{|c|}{ Plant height $(\mathrm{cm})$} \\
\hline $\mathrm{X} 1=\mathrm{SAWS}+\mathrm{SAWOUTS}+\mathrm{CEWS}+\mathrm{CEWOUTS}-4 \mathrm{TEST}$ & $28.8^{\mathrm{ns}}$ & $120.76 * *$ & $134.88 * *$ & $110.46 * *$ \\
\hline X2 = SAWS + SAWOUTS - CEWS - CEWOUTS & $-10.48^{\mathrm{ns}}$ & $-14.38^{\mathrm{ns}}$ & $2.38^{\mathrm{ns}}$ & $10.6^{\mathrm{ns}}$ \\
\hline X3 = SAWS - SAWOUTS & $-8.02^{\text {ns }}$ & $5.55^{\mathrm{ns}}$ & $5.97^{\mathrm{ns}}$ & $20.53 * *$ \\
\hline \multirow[t]{2}{*}{ X4 = CEWS - CEWOUTS } & $2.1^{\mathrm{ns}}$ & $3.07^{\text {ns }}$ & $-8.85^{\mathrm{ns}}$ & $6.57^{\mathrm{ns}}$ \\
\hline & \multicolumn{4}{|c|}{ Dry mass of the aerial part(g per plant) } \\
\hline $\mathrm{X} 1=\mathrm{SAWS}+\mathrm{SAWOUTS}+\mathrm{CEWS}+\mathrm{CEWOUTS}-4 \mathrm{TEST}$ & $0.75^{\mathrm{ns}}$ & $17.74 * *$ & $20.69 * *$ & $20.12 * *$ \\
\hline X2 = SAWS + SAWOUTS - CEWS - CEWOUTS & $-3.29^{\mathrm{ns}}$ & $-1.02^{\mathrm{ns}}$ & $0.63^{\mathrm{ns}}$ & $-1.08^{\mathrm{ns}}$ \\
\hline X3 = SAWS - SAWOUTS & $-2.1^{\mathrm{ns}}$ & $2.2^{\mathrm{ns}}$ & $4.1 * *$ & $1.72^{\mathrm{ns}}$ \\
\hline \multirow[t]{2}{*}{ X4 = CEWS - CEWOUTS } & $3.18^{*}$ & $1.32^{\mathrm{ns}}$ & $1.53^{\mathrm{ns}}$ & $0.7^{\mathrm{ns}}$ \\
\hline & \multicolumn{4}{|c|}{ Grain productivity $\left(\mathrm{kg} \mathrm{ha}^{-1}\right)$} \\
\hline $\mathrm{X} 1=\mathrm{SAWS}+\mathrm{SAWOUTS}+\mathrm{CEWS}+\mathrm{CEWOUTS}-4 \mathrm{TEST}$ & $-825^{\mathrm{ns}}$ & $1018^{*}$ & $1205^{*}$ & $1132 *$ \\
\hline $\mathrm{X} 2=\mathrm{SAWS}+\mathrm{SAWOUTS}-\mathrm{CEWS}-\mathrm{CEWOUTS}$ & $35^{\mathrm{ns}}$ & $-510^{*}$ & $-319^{\text {ns }}$ & $104^{\mathrm{ns}}$ \\
\hline $\mathrm{X} 3=\mathrm{SAWS}-\mathrm{SAWOUTS}$ & $55^{\mathrm{ns}}$ & $70^{\mathrm{ns}}$ & $171^{\mathrm{ns}}$ & $236^{\mathrm{ns}}$ \\
\hline X4 = CEWS - CEWOUTS & $306^{\mathrm{ns}}$ & $490 * *$ & $288^{\text {ns }}$ & $174^{\mathrm{ns}}$ \\
\hline
\end{tabular}

$*$, ** Significant at 5 and $1 \%$ probability, respectively, by the $\mathrm{F}$ test. $\mathrm{ns}=$ Non-significant.

SAWS $=$ S. aterrimum with straw kept in the area; SAWOUTS $=$ S. aterrimum without straw kept in the area; CEWS $=$ C. ensiformis with straw kept in the area; CEWOUTS $=$ C. ensiformis without straw kept in the area; and TEST $=$ without prior cultivation with weeded area. 

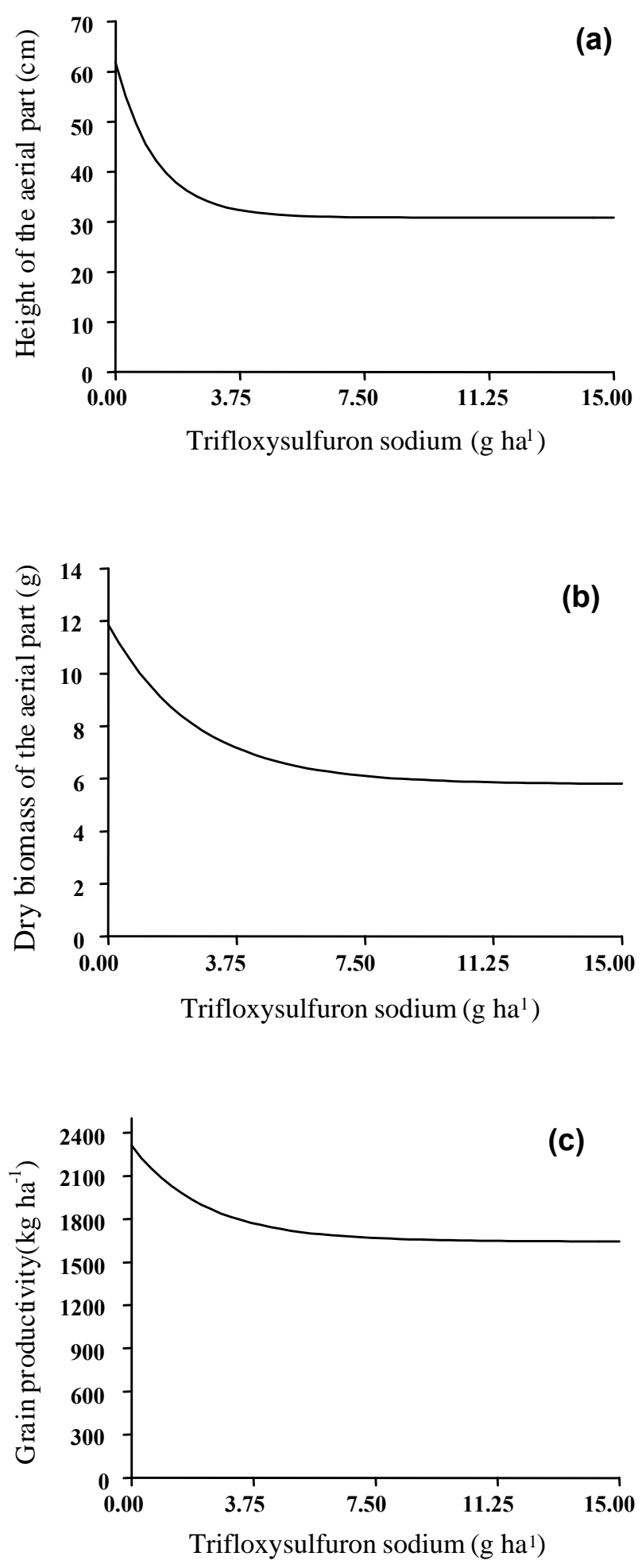

Figure 1 - Height (a), and dry mass of the aerial part (b) of bean plants at 45 days after sowing and grain productivity (c) during harvest in soil contaminated with different levels of the herbicide trifloxysulfuron-sodium, without prior cultivation of $S$. aterrimum and $C$. ensiformis, in a weeded kept area. Coimbra, $\mathrm{MG}$ - Brazil.
Analyzing Figure 1b and Table 4, it can be confirmed that the dry mass of the aerial part of the bean plants cultivated after the soil was kept cleared for 80 days decreased with the increase of the trifloxysulfuron-sodium doses; however, the greatest decrease was verified at the dose of $3.75 \mathrm{~g} \mathrm{ha}^{-1}$, a fact already reported about plant height. The evaluation of such characteristics again indicates that small levels of this herbicide in the soil can cause a reduction in the growth rate of the bean plants. The previous action of S. aterrimum and C. ensiformis attenuated the phytotoxic action of the herbicide, maintaining the mass of the aerial part of the bean plants, at all levels of trifloxysulfuron-sodium contamination, very close to that verified in the treatments without herbicide application (Tables 2 and 4).

In the areas not contaminated with trifloxysulfuron-sodium, bean productivity in the plots with prior cultivation did not differ from those verified in the treatments where the leguminous plants $S$. aterimum or C. ensiformis were cultivated (Tables 2 and 3 - contrast X1). In the absence of residual activity of the herbicide in the soil, S. aterrimum and C. ensiformis presented similar effects, not interfering in the productivity of the culture (Table 3 - contrast X2), with permanence or removal of straw of these leguminous plants not influencing bean productivity (Table 3 contrasts X3 and X4). As seen for plant height and dry mass of the aerial part, the permanence of both $S$. aterimum and $C$. ensiformis straw did not harm culture productivity, even being a succession involving species belonging to the same botanical family (Fabaceae).

For all levels of soil contamination with trifloxysulfur on-sodium, phytoremediation by the leguminous plants $S$. aterrimum and C. ensiformis was always found to result in higher bean plant productivity, compared to the treatments without prior cultivation (Tables 2 and 3 - contrast X1). When the lowest herbicide dose was applied $\left(3.75 \mathrm{~g} \mathrm{ha}^{-1}\right)$, it was verified that the action of the $C$. ensiformis plants resulted in greater productivity for the bean culture cultivated in succession than that of S. aterrimum. Similar results were not verified at higher contamination levels $(7.50$ and $15.00 \mathrm{~g} \mathrm{ha}^{-1}$ ), with no difference in bean 
Table 4 - Fitted equation correlating height and dry mass of the aerial part (DMAP) of plants at 45 days after sowing and grain productivity of bean (Phaseolus vulgaris Vermelho Coimbra cv.), in area contaminated with different doses of the herbicide trifloxysulfuron-sodium (D), with and without prior cultivation of two green manure species, Coimbra, MG

\begin{tabular}{|c|c|c|}
\hline Phy toremediation & Equation & $\mathrm{R}^{2}$ \\
\hline & \multicolumn{2}{|c|}{ Plant height $(\mathrm{cm})$} \\
\hline S. aterrimum with straw kept in the area & $Y=65.95$ & - \\
\hline S. aterrimum without straw kept in the area & $Y=59.94$ & - \\
\hline C. ensiformis with straw kept in the area & $\mathrm{Y}=64.79$ & - \\
\hline C. ensiformis without straw kept in the area & $Y=64.07$ & - \\
\hline \multirow[t]{2}{*}{ Without prior cultivation with weeded area } & $\hat{\mathrm{Y}}=30.873+\exp (3.435+(-0.818) * \mathrm{D})$ & 0.99 \\
\hline & \multicolumn{2}{|c|}{ Dry mass of the aerial part(g per plant) } \\
\hline S. aterrimum with straw kept in the area & $Y=11.88$ & - \\
\hline S. aterrimum without straw kept in the area & $Y=10.41$ & - \\
\hline C. ensiformis with straw kept in the area & $Y=12.58$ & - \\
\hline C. ensiformis without straw kept in the area & $\mathrm{Y}=10.90$ & - \\
\hline \multirow[t]{2}{*}{ Without prior cultivation with weeded area } & $\hat{\mathrm{Y}}=5.793+\exp (1.806+(-0.396) * \mathrm{D})$ & 0.99 \\
\hline & \multicolumn{2}{|c|}{ Grain productivity $\left(\mathrm{kg} \mathrm{ha}^{-1}\right)$} \\
\hline S. aterrimum with straw kept in the area & $Y=2029$ & - \\
\hline S. aterrimum withouttraw kept in the area & $\mathrm{Y}=1896$ & - \\
\hline C. ensiformis withstraw kept in the area & $Y=2206$ & - \\
\hline C. ensiformis without straw kept in the area & $\mathrm{Y}=1891$ & - \\
\hline Without prior cultivation with weeded area & $\hat{\mathrm{Y}}=1642.990+\exp (6.503+(-0.446) * \mathrm{D})$ & 0.99 \\
\hline
\end{tabular}

productivity being verified as a result of prior sowing of these two leguminous plants (Table 3 - contrast X2). The prior removal or permanence of $S$. aterrimum straw during the bean cycle did not alter the productivity of this culture (Table 3 - contrast X3). However, permanence of $C$. ensiformis straw in the area caused an increase in bean productivity only when $3.75 \mathrm{~g} \mathrm{ha}^{-1}$ of trifloxysulfuron-sodium was previously applied in the soil (Table 3 contrast X4). Results obtained under green house conditions, involving S. aterrimum and C. ensiformis, have confirmed the possibility of applying phytoremediation, showing that with just one cultivation of these species, expressive reductions are obtained in toxicity of sensitive species, such as maize and bean, cultivated in soils contaminated with trifloxysulfuron-sodium (Santos et al., 2004a, b; Procópio et al., 2004).

Increased doses of trifloxysulfuron-sodium decreased bean grain productivity only when prior soil remediation was not performed using the cover leguminous plants (Figure $1 \mathrm{c}$ and
Table 4). Again, a greater decrease in bean productivity was observed close to $3.75 \mathrm{~g} \mathrm{ha}^{-1}$, i.e., at relatively low levels of contamination, justifying the long herbicide application waiting interval before planting a sensitive culture in the area (around 8 months), recommended by the manufacturer.

The implementation of phytoremediation - a technique of prior decontamination of areas presenting trifloxysulfuron-sodium residues - using the species $S$. aterrimum and C. ensiformis, allowed anticipating bean cultivation in these sites up to six months. It should be emphasized that such species are classified as green manures, their cultivation also providing other benefits to soil fertility and conservation, besides decontamination.

\section{LITERATURE CITED}

ANDERSON, T. A.; COATS, J. R. Screening rhizosphere soil samples for the ability to mineralize elevated concentrations of atrazine and metolachlor. J. Environ. Sci. Health, v. 30, p. 473-484, 1995. 
ANDERSON, T. A.; KRUGER, E. L.; COATS, J. R. Enhanced degradation of a mixture of three herbicides in the rhizosphere of a herbicide-tolerant plant. Chemosphere, v. 28, p. 1551-1557, 1994.

BRIGSS, G. G.; BROMILOW, R. H.; EVANS, A. A. Relationship between lipophylicity and root uptake and translocation of non-ionized chemicals by barley. Pestc. Sci. v. 13, p. 495-504, 1982.

BURKEN, J. G.; SCHNOOR, J. L. Phytoremediation: plant uptake of atrazine and role of root exudates. J. Environ. Engin., v. 122, p. 958-963, 1996.

BURKEN, J.G.; SCHNOOR, J. L. Uptake and metabolism of atrazine by poplar trees. Environ. Sci. Technol., v. 31, p. 1399-1406, 1997.

CATANEO, A. C. et al. Atividade de glutationa s-transferase na degradação do herbicida glyphosate em plantas de milho (Zea mays). Planta Daninha, v. 21, p. 307-312, 2003.

CUNNINGHAM, S. D.; ANDERSON, T. A.; SCHWAB, A. P. Phytoremediation of soils contaminated with organic pollutants. Adv. Agron., v. 56, p. 55-114, 1996.

DIETZ, A.; SCHNOOR, J. L. Advances in phytoremediation. Environ. Health Perspec., v. 109, p. 163-168, 2001.

DOTY, S. L.. et al. Metabolism of the soil and groundwater contaminants, ethylene dibromide and trichloroethylene, by the tropical leguminous tree Leuceana leucocephala. Water Res., v. 37, p. 441-449, 2003.

\section{EMPRESA BRASILEIRA DE PESQUISA}

AGROPECUÁRIA - EMBRAPA. Manual de métodos de análise de solo. 2.ed. Rio de Janeiro: Centro Nacional de Pesquisa de Solos. 212 p. 1997.

FERNANDES, R. T. et al. Evaluating semiaquatic herbaceous perennials for use in herbicide phytoremediation. J. Am. Soc. Hort. Sci., v. 124, p. 539-544, 1999.

FERRO, A. M.; SIMS, R. C.; BUGBEE, B. Hycrest crested wheatgrass accelerates the degradation of pentachlorophenol in soil. J. Environ. Qual., v. 23, p. 272-279, 1994.

HOLT, D. C. et al. Characterization of the safener-induced glutathione S-transferase isoform II from maize. Planta, v. 196, p. 295-302, 1995.

KVESITADZE, G. et al. Some aspects of the enzymatic basis of phytoremediation. J. Biol. Phys. Chem., v. 1, p. 49-57, 2001.
MACEK, T.; MACKOVÁ, M.; KÁŠ, J. Exploitation of plants for the removal of organics in environmental remediation. Biotechnol. Adv, v. 18, p. 23-34, 2000.

MANNERVIK, B.; DANIELSON, U. H. Glutathione transferases: structure and catalytic activity. CRC Crit. Ver. Biochem., v. 23, p. 283-337, 1988.

NATIONAL REGISTRATION AUTHORITY FOR AGRICULTURAL AND VETERINARY CHEMICALS. Trifloxysulfuron sodium in the product envoke herbicide. Camberra, Austrália. 2002. 39 p.

NEWMAN, L. A. et al. Uptake and biotransformation of trichloroethylene by hybrid poplars. Environ. Sci. Technol. v. 31, p. 1062-1067, 1997.

PERKOVICH, B. S. et al. Enhanced mineralization of $\left[{ }^{14} \mathrm{C}\right]$ atrazine in Kochia scoparia rhizosferic soil from a pesticidecontaminated site. Pestic. Sci., v. 46, p. 391-396, 1996.

PIRES, F. R. et al. Seleção de plantas tolerantes ao tebuthiuron e com potencial para fitorremediação. R. Ceres, v. 20, p. $583-594,2003$ a.

PIRES, F. R. et al. Seleção de plantas com potencial para fitorremediação de tebuthiuron. Planta Daninha, v. 21, p. 451-458, 2003b.

PROCÓPIO, S. O. et al. Seleção de plantas com potencial para fitorremediação de solos contaminados com o herbicida trifloxysulfuron sodium. Planta Daninha, v. 22, p. 315-322, 2004.

RICE, P. J.; ANDERSON, T. A.; COATS, J. R.

Phytoremediation of herbicide-contaminated surface water with aquatic plants. In: Phytoremediation in soil and water contaminants. Washington, DC: American Chemical Society, p. 133-151, 1997.

SALT, D. E.; SMITH, R. D.; RASKIN, I. Phytoremediation. Ann. Rev. Plant Physiol., v. 49, p. 643-668, 1998.

SANTOS, J. B. et al. Seletividade do herbicida trifloxysulfuron sodium para fins de fitorremediação. R. Ceres, v. 51, p. 129-141, 2004a.

SANTOS, J. B. et al. Fitorremediação do herbicida trifloxysulfuron-sodium. Planta Daninha, v. 22, p. 323-330, 2004b.

SCHNOOR, J. L. Phytoremediation. Pittusburgh, PA: GWRTAC 37 p. 1997.

WILSON, P. C.; WHITWELL, T.; KLAINE, S. J. Metalaxyl and simazine toxicity to and uptake by Typha latifolia.

Achiv. Environ. Contam. Toxicol., v. 39, p. 282-288, 2000. 